\title{
COMPARATIVE STUDIES OF PITUITARY GLAND EXTRACT, OVAPRIN HORMONE AND COST BENEFIT ON HATCHABILITY AND FRY QUALITIES OF CATFISH (CLARIAS GARIEPINUS)
}

\author{
Usman M.B., Olukotun O., Suleiman R., Aasa O.S., Apene E., Obekpa N.B., \\ Rasheed F.M., Afolabi A.O., Okechalu S.O., \\ Federal College of Forestry Mechanization of Afaka \& National Water Resources Institute, \\ Kaduna, Nigeria
}

Asuquo J.N.

College of Agriculture and Animal Science of Mando, Kaduna, Nigeria

*E-mail: oolugoke@yahoo.com

\begin{abstract}
This study examined the Hatchability, growth performance and profitability of Clarias gariepinus hatched with Ovaprim and pituitary hormone using reproductive output and fry quality indices. Six pairs of broods stock (Cat fish) with three pairs, each for artificial and natural hormones were selected from both male and female and were subjected to different treatment with ova prim (Artificial hormone) and pituitary gland extract (natural hormones). At a mean temperature of $25.0 \pm 0.81$ latency period for ova prim and pituitary gland extract were 650 and 698 minutes, respectively. Workers fecundity was significantly higher $(P<0.05)$ for brooders treated with ova prim than pituitary hormone induced spawners. Hatching rates also followed the same trend, in which significantly higher hatching success was recorded for ova prim ovulated eggs (90.2\%) than the pituitary hormone induced eggs $(70.33 \%)$ fry survival rate was $91.7 \pm 1.20 \%$ for Ovaprim induced fish while pituitary hormone induced fish fry had $87.8 \pm 1.23 \%$; percentage deformed fry was significantly minimal for Ovaprim treated fish. Production cost analysis revealed the use of pituitary produced a statistically significant gross profit and a higher profit index of 99.22 over the Ovaprim although Ovaprim was productive with a good yield for the cost amount. It was concluded from the study is that Ovaprim is superior hence it was recommended for use by catfish breeders while further research is been conducted on the use of pituitary hormone.
\end{abstract}

\section{KEY WORDS}

Artificial means, natural means, hormones, Profitability index.

Fish is a vital source of food for people. It is the most important single source of highquality protein providing about $16 \%$ of animal protein produced by the world population (FAO 1997). It is an important protein source in regions where livestock is relatively scarce. FAO (2000) states that fish supplied more than $10 \%$ of animal protein consumed in North America and Europe, $20 \%$ in Asia, 22\% in China and 17\% in Africa while in Nigeria it is estimated to be 40\% (Adewumi, 1994).

The demand for fish production is about 2.7 million metric tonne per annum with local production accounting for 800,000 metric tonne only leaving a large deficit of 1.9 metric tonne being met by importation (Daily Trust, 2014).

Catfish (Clarias gariepinus) is one of the most cultured fish species in Nigeria. Eliot (1995) reported that the culture of catfish (Clarias gariepinus) through hypophysation was initiated in Western Nigeria in 1973 with the trial in Clarias lazera collected from Ogbese River. Since then its culture has increased tremendously. Olauneya (1986), in a fish demand survey asserted that in Nigeria the catfish was the most preferred (about $60 \%$ of total fish demand), it out classed tilapia, carp and other fresh water species by a wide margin. The importance attached to culture of catfish in Nigeria is not only because it commands high market value but it can also tolerate low dissolve oxygen level and other adverse conditions 
where most other species cannot survive (Omitoyin, 1989). These qualities coupled with its low bone content, fine flavor, high growth rate and its ability to feed on virtually any type of feed makes it the preferred among the culturable species even though currently it is faced with incessant disease outbreak of stunted and poor growth rate and cannibalism due to poor management system.

Until the last 1980's most of the fish seeds including C. gariepinus used for aquaculture in Nigeria were collected from the wild. But aquaculture that is depending on wild bred fish seeds is fraught with several disadvantages such as inadequate supply of fish seed required to meet the production target of farmers. Meanwhile, adequate supply of quality seed is an essential prerequisite to successful aquaculture production (Rottmann et al., 1991). To guarantee adequate supply of fingerlings with known age and genetic background, several studies have been carried out which recent findings have led to improved techniques in induced breeding of C. gariepinus (Nwokoye et al., 2007).

In order to bridge fingerlings demand-supply gap, hatchery techniques have been developed for seed production of some culturable fish species. These are either through natural breeding in captivity or by induced breeding using exogenous ovulating agents, which trigger the ripening of matured eggs (Ajah, 2007). In Africa, various hormonal substances (Ovaprim, carp pituitary, human chorionic gonadotropin, frog pituitary extracts etc) have been used to induce breeding in fish with varying magnitudes of success (Okoro et al., 2007). There is therefore the need to carryout comparative studies on the effectiveness of these induction agents in order to obtain the viable options.

The need for this study arises from the fact that hatchery remains the most critical in the whole cycle of fish production and growth performance. Fish available for consumption and circulation in the country are gotten from artisanal (Small scale) Fishery, characterized by remoteness and difficulties mostly in area of hatching. Therefore, the effort to overcome these problems necessitated the need to access and determine the most efficient and convenient methods of fish propagation in order to meet the ever increasing demand for fish.

The study therefore compares the use of pituitary gland extracts and Ovaprim hormones in induced breeding and fry quality of Clarias Gariepinus.

\section{MATERIALS AND METHODS OF RESEARCH}

The experiment was carried out in the fisheries unit, College of Agriculture and Animal Science, Mando, Kaduna. The college is located on longitude $11^{\circ} 10^{\prime}$ North and latitude $07^{\circ}$ 38 'East with elevation of $632 \mathrm{~m}$ above sea level. It has an annual average rainfall of $1200 \mathrm{~mm}$ with $96 \%$ falling between April and October. The temperature varies between $26-35^{\circ} \mathrm{C}$. The humidity at harmattan period is between 21 and $27 \%$. Mando is located in the Northern Guinea Savannah zone of Nigeria.

Six gravid female $C$. gariepinus fish and six mature male fish with weight ranging from $1000 \mathrm{~g}-1500 \mathrm{~g}$ were purchased from the Fisheries Department of College of Agriculture and Animal Science Mando Kaduna. All broodfish were selected by external morphological characteristics. Females were selected on the basis of their bulging abdomen as well as egg colour. The selected fish were kept in an outdoor concrete tank $(2.5 \mathrm{~m} \times 2.0 \mathrm{~m} \times 1.5 \mathrm{~m})$ at Fisheries Department of College of Agriculture and Animal Science Mando Kaduna Demonstration Farm for seven days prior to the breeding date. They were fed $5 \%$ of total biomass with Coppens pelleted fish feed (48\% crude protein) twice daily. Feeding was suspended a day prior to the hormonal treatments.

Pituitary gland was extracted from some of the male brood fish; they were weighed so as to get a corresponding weight to that of recipient fish. The head of the male donor was cut off after stunning the fish and subsequently the lower jaw was cut off, the virtual side of the brain was opened to expose the pituitary gland, the glands was collected with a pair of tweezers and placed in a beaker containing $2 \mathrm{ml}$ of $0.9 \%$ normal saline solution. Each of the gland was crushed in a mortar using a pestle. Two millimeter of $0.9 \%$ normal saline solution was added and the suspension decanted and collected into a $2 \mathrm{ml}$ syringes. The freshly collected pituitaries were immediately injected into the female spawners. 
The hormone Ovaprim was purchased commercially at an Agro-Allied outlet located in Mando. Clear distilled water was added and then a dose of $0.5 \mathrm{ml}$ Ovaprim was administered to the female brood fish at $0.5 \mathrm{ml}$ Ovaprim $/ \mathrm{kg}$ of body weight. The Fish was injected inbetween the lateral line and dorsal fin. The male fish was killed, the abdomen dissected carefully and their milt sac obtained. The weight of each male was obtained and recorded alongside the weight of each of the gonad. A small incision was made on the lobes with a sharp razor blade and the milt was squeezed into a dry Petridish. Milt was waded into a Petridish with $0.9 \%$ normal saline solution.

Latency period was recorded for each of the fish in each group and stripping was done within 10 and 12 hours after injection with slight pressure at the ventral part of the abdomen, the ovulated eggs were allowed to ooze out freely and then collected into a dry Petridish of known weight. A sample of $1 \mathrm{~g}$ of the stripped eggs from each female were collected and fertilized by pouring the prepared milt into the eggs. The mixture of $1 \mathrm{~g}$ incubated separately on the spawning substrate, placed in water in each of the holding plastic containers. Post hatching, dead eggs were removed by siphoning, (the spawning, substrate was named and percentage hatchability determined by recording the number of dead eggs in each container.

Basic water quality parameters were determined; temperature was measured with a mercury in-glass thermometer. Dissolved oxygen and $\mathrm{pH}$ were measured using a dissolved oxygen and $\mathrm{pH}$ meter respectively.

Completely randomized design was employed. The experiment consists of two treatments; treatment one is $C$. gariepinus brood fish treated with the pituitary gland extract while treatment two is $C$. gariepinus treated with Ovaprim. Each treatment was replicated three times using plastics containers measuring $2.0 \mathrm{~m}$ in diametre and $0.84 \mathrm{~m}$ in height which were labeled, $T_{1} R_{1}, T_{1} R_{2}, T_{1} R_{3}$ and $T_{2} R_{1}, T_{2} R_{2}, T_{2} R_{3}$ for the $C$. gariepinus broodstock treated with pituitary and Ovaprim respectively. Each tank was provided with aeration facilities through a network of air pumps connecting tubules and diffuses. The brood stock was stripped and after fertilization the hatched larvaes were placed in these plastic containers

Latency period is the time taken from injection of female brood fish to time of stripping.

Workers fecundity was estimated by counting the number of eggs stripped from each female brood fish as follows.

\section{$F=$ Total weight of eggs $\times$ No of eggs per gram}

Relative Workers (Fecundity) was estimated by dividing the number of eggs stripped fecundity by the length per fish.

Percentage Hatchability was determined by estimating the number of unhatched egg:

$$
\% \text { Hatchability }=\frac{\text { Total no egg incubates }}{\text { No of unhatched egg }} \times 100 \%
$$

The survival rate per rearing tank was determined at the end of the experimental period with the formula:

$$
\% \text { Survival }=\frac{\text { no of survival fry }}{\text { Total no fry stocked }} \times 100 \%
$$

The percentage of deformed fry per rearing tanks was determined as follows.

$$
\% \text { deformity }=\frac{\text { no of deformed fry }}{\text { Total no of fry }} \times 100 \%
$$

Measure of profitability indicates the amount of money return to the investor on every naira invested was used to determine the profitability for each of the treatment. A modified Return per Capital Invested (RPCl) applied is specified as:

$$
\mathrm{RPCI}=\frac{\text { income Realised }}{\text { Total Revenue }}
$$


The data collected were subjected to analysis of variance (ANOVA) and the means were separated with least significant difference (LSD) using SAS statistical package.

\section{RESULTS AND DISCUSSION}

The result of the mean value of physico-chemical properties of water used in incubation and rearing tanks is presented in Table 1 . The mean dissolved oxygen of the treatments was between $6.46-6.90 \mathrm{mg} / \mathrm{L}$, temperature ranged between $25.00-25.50^{\circ} \mathrm{C}$ and the $\mathrm{pH}$ mean values 6.90. Weatherly (1990) described fish growth as the end product and an integrator of the reactions involving the intrinsic and extrinsic factors (including the aquatic medium) in which the fish finds itself. It has been established that specific features of the catfish environment are of primary importance in determining the growth and survival of the fish species. The dissolved oxygen of the treatments was between $6.46-6.90 \mathrm{mg} / \mathrm{L}$; temperature, $25.00-25.50{ }^{\circ} \mathrm{C}$ and $\mathrm{pH}, 6.90$. These values fall within the range (3.0- $9.0 \mathrm{mg} / \mathrm{L}$ for dissolved oxygen), $\left(24.00-32.00^{\circ} \mathrm{C}\right.$ for temperature) and (6.50 -9.00 for $\mathrm{pH}$ ) reported by Boyd (1997) as the best for tropical fishes.

Table 1 - Mean values of physico-chemical parameters of water

\begin{tabular}{|l|l|l|}
\hline Parameters & Incubation tank & Rearing tank \\
\hline Dissolved Oxygen $(\mathrm{mg} / \mathrm{l})$ & 6.90 & 6.46 \\
\hline Temperature $\left({ }^{\circ} \mathrm{C}\right)$ & 25.00 & 25.50 \\
\hline $\mathrm{P}^{\mathrm{H}}$ & 6.90 & 6.90 \\
\hline
\end{tabular}

Table 2 shows the result of induction of Clarias gariepinus with Ovaprim and Clarias gariepinus pituitary gland extract. Mean weight of eggs was highest in $C$. gariepinus injected with the pituitary gland extract and was significantly different $(p<0.05)$ from Ovaprim. The fecundity was significantly different among hormone treatments. The fecundity of $\mathrm{C}$. gariepinus injected with Ovaprim was significantly higher $(p<0.05)$ than that of pituitary gland extract. Cannulation and stripping revealed that single intramuscular injection of Clarias pituitary gland extract and Ovaprim induced ovulation in all the female catfish at the specified dosage. Spawning and hatching of frying were observed in fishes treated with Clarias Pituitary gland extract and Ovaprim. Weight of breeders used in this experiment ranges from 1020-1050 g. Nearly all the fishes irrespective of their size and weight responded well to hormone injection and spawned within 11-12 h (latency period) at temperature range of $25.00-25.50^{\circ} \mathrm{C}$. This is in accordance with Viveen et al. (1985) that Clarias gariepinus are mature enough when they weigh between 200-500 g and above. Fertilization rate was high. C. gariepinus injected with Ovaprim had the highest percentage fertilization of $85.50 \%$ which was significantly different from that of pituitary gland extract of $61.50 \%$ as indicated in Table 1. The percentage hatchability was high and ranged from $70.33-90.20 \%$ in the different hormone treatments. The percentage hatchability shows similar pattern to percentage fertilization and latency period ranged between 10.83 hours in C. gariepinus injected with Ovaprim and 11.63 hours for $C$. gariepinus injected with pituitary gland extract. The percentage fertilization of $C$. gariepinus injected with Claria pituitary gland was $61.50 \%$. This is slightly lower than those reported by Fagbenro et al. (1991). This may be attributed to species difference and culture systems. The percentage fertilization of this study using Claria pituitary gland extract is nearly the same with that observed by Barua and Mollah (1987) on induced catfish Mystrus tengara using frog (Rana tigrina) pituitary extract and that of Adebayo and Popoola (2008) that obtained percentage fertilization of $62.00 \%$ in their study. The study showed the success of hypophysation in Clarias gariepinus. The hatching rate was $70.33 \%$ in Claria pituitary gland extract and $90.20 \%$ in Ovaprim. These values disagreed with Saidin (1986) who reported that artificial oviposition by stripping of $C$. macrocephalus gave low hatching rate of $10-45 \%$. However, the values are also higher than those reported by Adebayo and Popoola (2008) whose hatching rates ranged between $51.1-73 \%$ in the different hormone treatments and hatching rate of $25.99-46.30 \%$ reported by Olaniyi and Akinbola (2013) in their study. Generally, values obtained for the spawning response in the hormone treatments were significantly different $(P<0.05)$. The mean egg weight were 
significantly different $(\mathrm{P}<0.05)$ despite the fact that body weight of the females were approximately the same. However, the injection induced ovulation in all the female Catfishes at the specified dosage.

Table 2 - Mean values of reproductive indices of $C$. gariepnus brood fish induced to breed with Ovaprim and pituitary gland hormones

\begin{tabular}{lllll}
\hline & & & \\
Parameters & \multicolumn{1}{c}{ Pituitary gland } & Ormones & SEM & LS \\
\cline { 3 - 5 } & 1020.00 & 1050.00 & 14.01 & $\mathrm{NS}$ \\
Body weight(g) & $30798.20 \mathrm{~b}$ & $35025.00 \mathrm{a}$ & 945.19 & $*$ \\
Recundity & $635.40 \mathrm{~b}$ & $725.00 \mathrm{a}$ & 20.04 & $*$ \\
Egg weight (g) & $25.25 \mathrm{a}$ & $17.08 \mathrm{~b}$ & 2.02 & $*$ \\
Fertilization (\%) & $61.50 \mathrm{~b}$ & $85.50 \mathrm{a}$ & 3.51 & $*$ \\
Hatchability (\%) & $70.33 \mathrm{~b}$ & $90.20 \mathrm{a}$ & 4.44 & $*$ \\
Hatching period (h) & 72.00 & 72.00 & 3.05 & $\mathrm{NS}$ \\
Latency(h) & 11.63 & 10.83 & 1.09 & $\mathrm{NS}$ \\
\hline
\end{tabular}

Means in the same row with different superscripts $(a, b)$ are significantly different $(P<0.05)$,SEM : standard error of mean, LS: Level of significance, * : significant at $5 \%$ level of probability and NS: Non-Significant.

The result of survival and rate of deformity of progeny of $\mathrm{C}$. gariepinus brood fish induced to breed with Ovaprim and pituitary gland extract in Table 3. Deformed fries were significantly lower in C. gariepinus injected with Ovaprim (0.25\%) than C. gariepinus injected with pituitary gland extract $0.90 \%$ ). Survival rate of fries after 4 weeks was $91.70 \%$ in Ovaprim and $87.80 \%$ in Claria pituitary gland extract. This was higher than the range of $30.00-66.00 \%$ reported by Adebayo and Popoola (2008)and that ofOlaniyi and Akinbola (2013) who observed survival rate of $50.14 \%$ in Ovaprim and $82.98 \%$ in Claria pituitary gland extract in their study.

Table 3 - Survival and rate of deformity of progeny of $C$. gariepinus broodfish induced to breed with Ovaprim and pituitary gland extract hormones

\begin{tabular}{llll}
\hline Parameters & Pituitary gland extract & Ovaprim & SEM \\
\hline Fry weight $(\mathrm{g})$ & $0.08 \mathrm{~b}$ & $0.14 \mathrm{a}$ & 0.01 \\
Deformed fries (\%) & $0.90 \mathrm{a}$ & $0.25 \mathrm{~b}$ & ${ }^{*}$ \\
Survival rate (\%) & $91.70 \mathrm{a}$ & $87.80 \mathrm{~b}$ & 0.16 \\
\hline
\end{tabular}

Means in the same row with different superscripts $(a, b)$ are significantly different $(P<0.05), S E M$ : standard error of mean, LS: Level of significance, ${ }^{*}$ : significant at $5 \%$ level of probability and NS: Non-Significant.

Table 4 - Comparative cost benefit analysis of Ovaprim and pituitary gland extract hormones for inducing breeding in C. gariepinus

\begin{tabular}{lllll}
\hline Parameters & Pituitary gland & \multicolumn{3}{c}{ Hormones } \\
\cline { 3 - 5 } & $50000.00 \mathrm{~b}$ & Ovaprim & SEM & LS \\
\hline Net production (No) & $1600.00 \mathrm{~b}$ & $3000.00 \mathrm{a}$ & 24.87 & $*$ \\
Cost of production (Naira) & $200000.00 \mathrm{~b}$ & $320000.00 \mathrm{a}$ & 68.34 & $*$ \\
Value of fries & $198400.00 \mathrm{~b}$ & $317000.00 \mathrm{a}$ & 62.67 & $*$ \\
(Naira) & 99.22 & 99.06 & 6.08 & NS \\
Gross profit (Naira) & Profit index (\%) &
\end{tabular}

Means in the same row with different superscripts $(a, b)$ are significantly different $(P<0.05), S E M$ : standard error of mean, LS: Level of significance, ${ }^{*}$ : significant at $5 \%$ level of probability and NS: Non-Significant.

The results of economic evaluation of using Clarias pituitary gland extract and Ovaprim to induce ovulation and spawning in $C$. gariepinus is presented in Table 4. The result revealed that hormones sources have a highly significant effect on net production of $C$. gariepinus. The cost of production was significantly highest in Ovaprim and least in pituitary gland extract $(p<0.05)$.Also, the value of fish was highest in Ovaprim and was significantly different from that of pituitary gland extract. Profit index for $C$. gariepinus injected with Ovaprim and C. gariepinus injected with pituitary gland extract were statistically similar with the values of $99.06 \%$ and $99.22 \%$ respectively. Cost of production using pituitary gland extract wa slower than cost of production using Ovaprim. This follows the same pattern as 
reported by Adebayo and Popoola. (2008) but not in agreement with Olaniyi and Akinbola (2013) who reported higher cost of production using pituitary gland extract compare to using Ovaprim.

\section{CONCLUSION}

This research showed that greatest profit index was realized from female fish injected with pituitary gland extract compare to the ones injected with Ovaprim. Since the main goal of any fish farming enterprise is to maximize profit, it can be concluded that African Catfish pituitary extract should be used to aid spawning in African Catfish. It is suggested that fish seed production can be encouraged through the use of natural hormone such as Clarias pituitary gland extract which is more readily available unlike ova prim whose supply varies with changes in import duties.

\section{REFERENCES}

1. Adebayo O. T. and Popoola O.M (2008). Comparative Evaluation of Efficiency and Cost of Synthetic and Non-Synthetic hormone for Artificial Breeding of African Catfish (Clarias gaiepinus), Journal of Fish Aquaculture Science. 3:66-71.

2. Adewumi M. O. (1994) Economics of Cat Fish in River State, Nigeria. In Proceedings of the $23^{\text {rd }}$ Annual Conference of Farm Management Society of Nigeria (Sokoto) $14^{\text {th }}-17^{\text {th }}$ December, 2002 pp. 570.

3. Ajah.O. P. (2007). Fish Breeding and Hatchery Management. Jerry commercial production, Calabar, Nigeria. Pp52

4. Barua, $G$ and Mollah, M.F. (1987). Observations on the spawning Behaviour of Mystrus tengara (Ham). Bangladesh, Journal of Fish 10: 43-46.

5. Boyd, C.E. (1997). Effect of Ammonia in the water of the Culturable Clarias gariepinus. Int. centre for Aquaculture, agriculture Experiment Station. Auburn University pp. 10-30.

6. Daily Trust (2014). Daily Trust News Publication on August ! $4^{\text {th }}$ "Agriculture" pp. 29.

7. Eliot, O. O. (1995). Biological Observation of Some Species, Use for Aquaculture in Nigeria FAO/C.FFA Symposium on Aquaculture in Africa Ghana (IFA/75/SE 18.

8. Fagbenro, O.A., salami, A.A and Sydenhan, H.J. (1991). Induced Ovulation and Spawning in the Catfish (Clarias isheriensis) using Pituitary Extract from Non- piscine sources. Journal of Applied Aquaculture, 1: 15-20.

9. FAO (1997). The State of Fish: Aquaculture. Food and Agriculture Organization, Rome

10. Food and Agriculture Organization FAO, (2000). Fisheries Technical Paper 215/Unp FAO.

11. Nwokoye CO, Nwuba L A \& Eyo J E (2007). Induced propagation of African clariid catfish Heterobranchus bidorsalis (Geoffrey Saint Hillarie 1809), using synthetic and homoplastic hormones. African Journal of Biotechnology, 6(23): 2687-2693.

12. Okoro, C.B, Nwadukwe, F.O. Ibemere, I. (2007). The use of Ovaprim in oocyte maturation and ovulation in Clarias gariepinus (Burchell, 1822). African Journal of Applied Zoology and Environmental Biology, 9, 83-84.

13. Olaniyi, C.O and Akinbola, D.O (2013). Comparative Studies on The Hatchability, Performance and Survival Rate of African Catfish Larval Produced: Using Ovaprim and Catfish Pituitary Extract Hormones. J. of Biology, Agriculture and Healthcare. 3(9): 57-62.

14. Olauneya P. A. (1986) Enhancing Fisheries Development in Nigeria. The Case of River Basin Development Authority. Journal of West African Fisheries. 1:57-64.

15. Omintoyin, B.O (1989). Reproductive Performance of Clarias geriepinus Female Brood stock and Swim-up Fry and Graded calorie level diet. University of Ibadan, Nigeria.

16. Rottmann, R.W., Shireman, J., Chapman, F.A (1991). Introduction to Hormone - Induced Spawning of Fish. SRAC Publication, No. 421.

17. Saidin, T. (1986). Induced Spawning of Clarias macrocephalus (Gunther). The first Asian Fisheries Forum, pp. 683-686.

18. Weatherly, A.H. (1990). Approaches to understanding fish growth. Transactions of the American Fisheries Society, 119: 62-67. 